\title{
Roles and Responsibilities Land Deed Official (PPAT) Of Tax Duty in the Implementation of Acquisition of Land and Buildings (BPHTB) Underpayment by the Taxpayers in Semarang
}

\author{
Ahmad Khalimaya Nugroho ${ }^{1}$, Insan Al Ha Za Zuna Darma Illahi ${ }^{2}$ and Sri \\ Endah Wahyuningsih ${ }^{3}$
}

Abstract. The purpose of this research are: 1) To identify and analyze the role of responsibility in the Land Deed Official BPHTB implementation of extant underpayment by the taxpayer in the city of Semarang. 2) To know and understand the procedures for implementing the tax collection of BPHTB the underpayment by the taxpayer in the city of Semarang. 3) To analyze the barriers and solutions in tax collection is less paid by the taxpayer in the city of Semarang.

The methods of this research approach is empirical jurisdiction. Primary data was taken by the method of structured interviews, secondary data, and the data tertiary literature study and analysis by descriptive analytical method.

Based on the results of data analysis concluded that: 1) The role and responsibilities of PPAT can vary in terms of solving problems regarding the lack of pay taxes BPHTB, first there are some of PPAT to omit some chapters in a deed of them, and some are not stated with a settlement notice or in the form of an appeal as officials land deed to the client or taxpayers.2) procession conducted by the tax authorities namely Apparatus State Civil circulate bills of underpayment of tax is intended to taxpayers who are still their underpayment of tax by nature force because the circulars issued by phisicus accordance with rule and regulations in force in accordance with Regulation Semarang City No. 2 of 2011 Chapter VII Article 15 paragraph 1 and 2. 3) Barriers often happens is that first were often there is an error in the calculation of the nominal value of the deposit amount of tax to be paid by the taxpayer to the local government, the second presence at the crux on the amount of tax rates provided to the taxpayer by the SPPTPBB both rural and urban, as well as the steps being taken are in accordance with agreed procedures, but it is still the amount of load that must be paid by the taxpayer. The solution to these problems that is better than the Land Deed Official should conduct socialization to the client then later if there is any underpayment of tax.

Keywords: Empirical Juridical Review; Pay less Tax; Customs Tax Collection Procession Acquisition of Land

\section{Introduction}

Tax is a source of revenue for a country's most important that the tax has a very vital role as income a country both developing countries and developed countries. In Indonesia, the tax is one of the pillars of national income which contributed approximately $70 \%$ of state revenue. Of that need to be understood and known that the definition of tax in the opinion of Rochmat Soemitro is dues or contributions of the

\footnotetext{
${ }^{1}$ Student of Master of Notary Law, Faculty of Law, Sultan Agung Islamic University, Unissula, Semarang, email: ahmadkhalimaya@gmail.com

2 Student of Master of Law, Faculty of Law , Sultan Agung Islamic University, Semarang, email: damazuna@yahoo.com

${ }^{3}$ Faculty of Law, Sultan Agung Islamic University, Unissula, Semarang
} 
people against a State, under the law (enforceable) and by not got the services of reciprocity (contra) directly demonstrated and used to pay off public spending. ${ }^{4}$

Earned Value Tax Object (NPOP) was used as a basis for the imposition of BPHTB. Earned Value Tax Base Tax Object (NPOP DPP) obtained from a comparison between the highest value transaction value or the market value of the taxable value (SVTO). The highest value becomes NPOP DPP in calculating BPHTB.

In the imposition BPTHB, NPOP not directly multiplied by the highest rates of $5 \%$, but the deductible first with Earned Value Taxable Tax Object (NPOPTKP) which amount Rp.60.000.000,- and specifically for the acquisition of rights due to inheritance or testament deductible with NPOPTKP Rp.300.000.000,-. BPHTB charged to the taxpayer who may be an individual or a legal entity. ${ }^{5}$

Taxpayers calculate their own tax object BPHTB according to the tax base determined by the provisions of the tax and then pay for itself BPHTB with the Tax Payment Area (SSPD). This process is a calculation system of self assessment system. ${ }^{6}$ BPHTB collection system is regulated in Act No. 28 of 2009 Article 98 in conjunction with Government Regulation No. 91 of 2010.

One of the mayor's ordinance / decree is Semarang Mayor Regulation No. 2 of 2011 that in the calculation BPHTB before depositing, the tax authorities will conduct research SSPD to check the truth of such transferred object. Results of research conducted tax authorities set forth in the agreement and the research results included the signature and stamp duty on SSPD form that has been filled by the taxpayer. The amount of outstanding BPHTB listed in forms SSPD which has included the approval of the tax authorities on the research results as a basis for payment BPHTB. ${ }^{7}$ This shows as if the B PHTB using the official assessment system so contrary to the selfassessment system.

In the self assessment system that has given credence to the taxpayers need their supervisory functions, supervision and enforcement of the tax authorities. The function is implemented to create fairness and balance between taxpayers and tax authorities. The tax authorities are given the power to enforce the law against the tax due and the tax arrears of the taxpayer. Taxes in BPHTB billable by the tax authorities by using SPTPD, SKPDKB, and / or SKPDKBT. ${ }^{8}$

In terms of implementation of the taxation the transfer of the right to land, buildings need to gain an understanding and further studies in the review of the legal aspect. PPAT role in his capacity as General Officer in the notification to the client as well as an extension of the client is an important part when viewed from the aspect of taxation, especially for the sake of hold well BPHTB tax collection.

The purpose of this study is not just to find out but the authors have attempted to analyze the aspects contained in the title of the author of the scientific paper. The role and responsibilities of a PPAT, on procedures implementation, and analyze the barriers that become causes of the underpayment of tax by the taxpayer in the city of Semarang.

\section{Research methods}

\footnotetext{
${ }^{4}$ Mardiasmo, 2013, Perpajakan, Edisi Revisi, Andi Offset, Yogyakarta., p. 1

${ }^{5}$ Act No. 28 of 2009 on Regional Taxes and Levies.

6 Panca Kurniawan and Agus Purwanto, Pajak Daerah dan Retribusi Daerah di Indonesia, Bayumedia Publishing, Malang, 2004, p. 126-127

7 Semarang Mayor Regulation No. 2 of 2011 on Systems and Procedures Withholding Tax on Acquisition of Land and / or buildings.

${ }^{8}$ Act No. 28 of 2009 Article 96 Paragraph (5) of the Local Taxes and retribution
} 
Volume 6 Issue 4, December 2019

Nationally Accredited Journal,

Decree No. B/4130/E5/E5.2.1/2019

The method approach used in this research is the analysis using empirical jurisdiction. In this case the approach used to analyze qualitatively related to the Land Deed Official Role in the implementation BPHTB tax which was still their underpayment in Semarang. Specifications research using analytical descriptively. The description or objective reality obtained through studies that analyzed and collected from interviews with actors BPHTB tax implementation happened a shortfall paid by the taxpayer on a transfer of rights that occur. Said to be analytically because the results obtained, then analyzed using the legislation in force.

Primary data obtained by the author of interview, observation and observation of the first sources of Land Deed Official (PPAT) and Civil State Apparatus (ASN) obtained from research in the Office of the Regional Revenue Agency (Bapenda) Semarang. While the Secondary Data: this data through documentation.

This qualitative research is descriptive because the data being analyzed is not to accept or reject the hypothesis but rather a description of the symptoms observed to obtain a thorough understanding and utu about the different roles of the subject of research. ${ }^{9}$

\section{Results and Discussion}

\subsection{Role Responsibilities Land Deed Official BPHTB in the implementation of the remaining underpayment by the taxpayer in the city of Semarang.}

Land Deed Official Role in Implementation BPHTB actually only authorized to make the deed alone. However, in practice the field PPAT more of a role than the taxpayer in terms of helping calculate and pay the tax due. Because the taxpayer is usually authorizes PPAT to implement tax payment procession BPHTB it happens because the taxpayer does not know BPHTB and groove payment procession. PPAT also officials who are engaged in selling their services, it would provide an excellent service to its customers to help calculate and pay taxes of BPHTB.

PPAT roles and responsibilities may vary in terms of solving problems regarding the lack of pay taxes BPHTB, first there are some of PPAT omit many of the provisions in the deed of their as protection for a PPAT Deed Official Land, and some are not to omit the settlement notice or the provision of understanding as officials land deed to the client or taxpayers about the loads that will be charged to client or taxpayers, especially regarding BPHTB.

PPAT has a significant role in the implementation of tax BPHTB because for PPAT is the General Authorities involved in a wide variety of transactions transfer of rights, to do with taxes BPHTB a PPAT has an obligation every month for hands the report or notice of acquisition of land or buildings under the provisions of the applicable. Corresponding with article 29 paragraph (1) of Act No. 2 of 2011 determined that PPAT must report the acquisition of land and or building every month. The report on the number of SSB were out, the number of deed made. This report submitted to Board of Revenue (Bapenda) Semarang later than 10 (ten) each month. The report referred to at least the number and date of the deed, the status of rights, lay of the land, land area, building area, taxable value, the price transaction or market value, names and addresses of the parties change and who obtained the right and the date and amount

\footnotetext{
${ }^{9}$ M. Subana and Sudrajat, Dasar-Dasar Penelitan I/miah, Pustaka Setia, Bandung, 2005, p.17.
} 
of deposit ${ }^{10}$ This occurs as a step of (Bapenda) in Semarang as a clarification of the truth that is true has happened for the tax payment BPHTB with No. deed, the date of the Deed, located where, with a land area as stated in the certificate in land deed officials, based on the data in the possession of the Regional Revenue Agency. The match with the deed issued by the Land Deed Official Number and date it could certainly be used as an evidence of the truth, and a valid proof of tax payment.

\subsection{Billing Implementation Procedures BPHTB less tax paid by the taxpayer in Semarang}

The research process conducted by the tax authorities an administrative checks and the calculation of a taxpayer tax obligations. This check is not done testing the correctness of the determination of the tax based on the taxpayer merely a technical process and the administration of the tax liability of the taxpayer. The study of the tax authorities who find fault ere write or count that led to underpayment of tax obligations may be issued Taxpayer STPs local taxes on the underpayment. ${ }^{11}$

The tax authorities who conducted research on the tax on this BPTHB have similar provisions in the law PDRD that the tax authorities can issue certificates of the Regional Tax Bill of BPHTB to charge underpayment BPHTB on the taxpayer. Billing is equipped with an underpayment of administrative sanctions such as fines and / or flowers. The amount of penalties and / or interest is $2 \%$ (two percent) a month from the time the tax is payable. Fines and / or the maximum interest rate / at most $30 \%$ (thirty percent) or a maximum of 15 months. ${ }^{12}$

With the tax authorities authority under the Act to collect tax underpayment of tax by issuing a legal product that is STPs Customs Region Acquisition of Land and / or Building coupled with financial penalties and / or interest as well as administrative sanctions, if any. This case shows that an error count BPHTB of taxpayers so that charged less paid by the tax authorities using BPHTB STPD.

An important role of the State Civil Apparatus (ASN) as a supervisor, in the process of verification of the deposit file who want to be paid by the taxpayer, either rechecking the calculation of the amount of taxes, as well as the truth about the contents of the data are the responsibility of the State Civil Apparatus (ASN) from here when an error occurs both from the calculation of the tax, as well as from the difference between the money to pay either more or less normally file will be returned to the taxpayer, or in this case the person who has got the power of the taxpayer, to immediately restyled, but sometimes often file already completed the verification and has been paid in accordance with the already established on Land and Building Tax (PBB) there are still less pay this is common when transaction occurred at the beginning of the year in January and February where the Tax payable Land and Building Tax (SPPTPBB) the current year has not been published and there are usually specific policies of the regional government, well that's what makes the difference had usually pay, either more or less.

\subsection{Obstacles and Solutions in Tax Collection Less Paid by Taxpayers in the city of Semarang.}

\footnotetext{
${ }^{10}$ Results of interviews with Nur Wahyu Hidayat, SE., Sub. Bid. Tax Billing, 20 November 2019

${ }^{11}$ Act No. 28 of 2009 Article 100 Paragraph (1) Letter b on Taxes Regional and Retribution

12 Act No. 28 of 2009 Article 100 Paragraph (2) of the Local Taxes and Levies
} 
Volume 6 Issue 4, December 2019

Nationally Accredited Journal,

Decree No. B/4130/E5/E5.2.1/2019

The barriers that often happens is here not only as taxpayers who should be prosecuted thoroughly in the calculation but Deed Official Soil should also be required to choose a good understanding or qualified in these fields, meticulous in carrying out a mandate given than the client authorize General Authorities or PPAT and give transparantcy counseling or information to taxpayers, because here the technical largely Land Deed official providing services to taxpayers facing. Land Deed Official thus prosecuted Professional, honest, conscientious and trustworthy in carrying out its duties and authorities as the endorsee of the taxpayer. meticulous in carrying out a mandate given than the client authorize or PPAT Public Officials as well as provide counseling or information transparantcy to taxpayers, because here the technical largely Land Deed Official providing services to taxpayers facing. Land Deed Official thus prosecuted Professional, honest, conscientious and trustworthy in carrying out its duties and authorities as the endorsee of the taxpayer. meticulous in carrying out a mandate given than the client authorize or PPAT Public Officials as well as provide counseling or information transparantcy to taxpayers, because here the technical largely Land Deed Official providing services to taxpayers facing. Land Deed Official thus prosecuted Professional, honest, conscientious and trustworthy in carrying out its duties and authorities as the endorsee of the taxpayer.

\section{Closing}

\subsection{Conclusions}

Based on the research results can be concluded as follows

- Regarding the role and responsibilities of PPAT in participant on taxes BPHTB not merely finished in deed only, but an outline of the PPAT took part in the implementation of tax payments BPHTB and calculations with the intention of serving the client or taxpayers who want to take care of transfer of rights they. Because Notary / PPAT are service providers who sell to people skills and his ability to serve the needs above those of the client Notary / PPAT demanded competent and capable and honest so that professionals and is responsible for the job.

- The Apparatus State Civil herein possessed Special rights to examine the attachment BPHTB which is charged and is calculated by the taxpayer seta issued a circular underpayment of taxes in accordance with the law, here the role of contributing tax authorities investigate and check (verification) data that has been filled it is properly or there are some mistakes, and if it turns out there is a good error may be due to lie in the calculation of the tax authorities will recover the file to the taxpayer to be changed first.

- Regarding barriers that occur with regard to one calculation can be minimized by accuracy and accuracy in data entry as the basis for calculations and formulas contained in Act No. 28 of 2009 regarding Customs Acquisition of Land. Accuracy and precision of a Notary / PPAT is needed because the technical PPAT major role in the implementation of BPHTB.

\subsection{Suggestion}

- Not only in terms of the honesty of a PPAT required for competent, careful and meticulous from various aspects, aware of the problems faced by the client and try to find a solution to a problem faced by paraclient automatic in that demanding as 
PPAT clever, intelligent, and wise in taking a decision, the fulfillment of all aspects of the above authors think it can minimize a problem that occurs even before the problem occurred prevent creating a calm working atmosphere as well and does not burden the mind of the client and PPAT itself.

- The next suggestion may be more directed to the client authors hope the client also required careful to understand that which PPAT convey or what the tax authorities regarding either explanation, the procedures of payment and penalties if their error, so not all solely disalahakan to those diberikuasa disni the authors use a landing to PPAT, because PPAT also people who have been cautious, careful, careful. But sometimes there are still some technical obstacles that escaped beyond the predictions of a PPAT.

\section{References}

1) Results of interviews with Nur Wahyu Hidayat, S.E., Sub. Bid. Tax Billing, 20 November 2019.

2) Kurniawan Panca and Agus Purwanto, 2004, Pajak Daerah dan Retribusi Daerah di Indonesia, Bayumedia Publishing, Malang.

3) Mardiasmo, 2013, Perpajakan, Edisi Revisi, Andi Offset, Yogyakarta.

4) Sudrajat and M. Subana Sudrajat, 2005, Dasar-Dasar Penelitan IImiah, Pustaka Setia, Bandung.

5) Soekanto Soerjono and Sri Mamuji, 2007, Penelitian Hukum Normatif-Suatu Tinjauan Singkat, Raja Grafindo Persada, Jakarta.

6) Act No. 28 of 2009 on Regional Tax and Retribution Area.

7) Act No. 28 of 2009 Article 96 Paragraph (5) on Local Taxes and Retribution.

8) Act No 28 of 2009 Article 100 Paragraph (1) Letter b on Taxes Regional and Retribution.

9) Act No. 28 of 2009 Article 100 Paragraph (2) of the Local Tax and Retribution.

10) Semarang City Regional Regulation No. 2 of 2011 concerning Customs Acquisition Land and Buildings Semarang City.

11) Semarang Mayor Regulation No. 2 of 2011 on the System and Voting procedures Customs Acquisition Rights to Land and / or buildings. 